by means of a gruel obtained from crushed virgin females; serum from the second group was similarly adsorbed by males. In both sera the complement fixation reaction was made by using, as antigens, extracts of gruel of both males and females.

The results are presented in Table I:

TABLF I.

\begin{tabular}{|c|c|c|c|c|c|c|c|c|c|c|c|c|c|}
\hline \multirow[t]{2}{*}{$\begin{array}{l}\text { Material for } \\
\text { immunisation }\end{array}$} & \multirow[t]{2}{*}{$\begin{array}{l}\text { Material for } \\
\text { adsorption }\end{array}$} & \multicolumn{6}{|c|}{$\begin{array}{l}\text { Results with } \sigma^{\star} \sigma^{*} \text { antigen } \\
\text { (number of experiments) }\end{array}$} & \multicolumn{6}{|c|}{$\begin{array}{l}\text { Results with } 9+\text { antigen } \\
\text { (number of experiments) }\end{array}$} \\
\hline & & ++++ & +++ & +4 & + & \pm & - & ++++ & +++ & ++ & + & \pm & - \\
\hline$\delta^{A} \sigma^{x}$ & 우우 & 15 & 34 & 3 & 0 & 0 & 0 & 0 & 1 & 13 & 12 & 8 & 18 \\
\hline 우 & $\sigma ే$ & 0 & 7 & 11 & 12 & 4 & 8 & 2 & 7 & 10 & 11 & 4 & 8 \\
\hline
\end{tabular}

* The number of plusses indicates the degree of positive result of the complement fixation reaction, that is, of the absence of hæmolysis.

As evident from this table, the results are not free from defects, chief of which seems to be insufficient adsorption. Apparently the individual characteristics of the rabbits are also of importance, particularly in view of a certain percentage of comparatively weak positive reactions in the series of experiments in which the immunisation was made by means of male extract and the adsorption by means of female gruel, the male extract being used as an antigen.

In view of the possibility that the positive results of this latter series might be considered as due to antibodies formed not against the $Y$-chromosome but against products specific for the male plasm, another series of experiments was undertaken. Serum, derived by immunisation by means of Drosophila male extract and adsorbed by means of females of the same stock was, in addition, adsorbed by means of females of the type $X X Y$ (double adsorption being necessary because the latter females, taken from another stock, evidently differed genotypically from the first line).

The results of this series of experiments are presented in Table II :

TABLE II.

\begin{tabular}{|c|c|c|c|c|c|c|c|c|c|c|c|c|c|}
\hline \multirow[t]{2}{*}{$\begin{array}{l}\text { Material for } \\
\text { immunisation }\end{array}$} & \multirow[t]{2}{*}{$\begin{array}{l}\text { Material for } \\
\text { adsorption }\end{array}$} & \multicolumn{6}{|c|}{$\begin{array}{c}\text { Results with antigen } \\
\text { (number of experiments) }\end{array}$} & \multicolumn{6}{|c|}{$\begin{array}{c}\text { Results with antigen } \\
\text { (number of experiments) }\end{array}$} \\
\hline & & ++++ & +++ & ++ & + & \pm & - & $++t+$ & +++ & ++ & + & \pm & - \\
\hline$\sigma^{*} \sigma^{*}$ & oq $\boldsymbol{X X}$ and oq $\boldsymbol{X X Y}$ & 0 & 0 & 2 & 2 & 3 & 2 & 0 & 0 & 0 & 0 & $\overline{3}$ & 6 \\
\hline
\end{tabular}

Further experiments are in progress. Details as to technique and a detailed report on the results will be communicated elsewhere.
S. G. Levit.
S. G. Ginsburg.
V. S. KaLININ.
R. G. Feinberg.

Department of Genetics and the Immuno-Biological Laboratory, Maxim Gorky Medico-Genetical Research Institute, Moscow. May 28.

\section{Projection Method for Demonstration of Chromosomes in situ}

THE demonstration of chromosome preparations has suffered from two serious difficulties in the past. First, the solid form of the object has to be reconstructed from images at different focuses, and it is impossible to be sure that an inexperienced observer has been able to do this. Secondly, chromosome behaviour in general has to be reconstructed from the observation of a great many cells, and their separate demonstration to one student, let alone a large number, is out of the question.

In order to overcome these difficulties (for the summer course of this Institution) we have experimented with the projection of images of the chromosomes on a screen, such as is com. monly used for lower magnifications. We find that with a 10 ampère arc lamp, a strong condenser, and a water-ammonia heat-absorbing tank, a sufficient beam of light can be passed through the horizontal microscope (with a $\times 90$ oil immersion apochromatic objective, N.A. $1 \cdot 3$, and a $\times 5$ compensating eyepiece) to give a bright image magnified 5,000 diameters on a screen four feet in diameter and at a distance from the microscope of nine feet. The beam of light between the condenser and the microscope is enclosed to prevent glare. We find that a plain white screen is more satisfactory for our purposes than ground glass, opal glass, silvered or beaded screens. The microscope can be turned on a swivel, and the demonstration interrupted to show ordinary lantern slides.

This apparatus gives equally satisfactory results with well-differentiated hæmatoxylin and gentian. violet staining, with sections of root-tips and with smears of testes and pollen mother-cells. The form and internal structure of the chromosomes-their coiling and chiasmata-and the positions of such bodies as chromomeres and centromeres, $2000 \mathrm{~A}$. in diameter, ean be shown throughout the nucleus at focuses varying in depth $20-30 \mu$. They can be seen by ten or fifteen persons at once with our present experimental apparatus.

The use of this method should enable students to understand chromosomes in a real, and not merely a verbal sense. The apparatus can be made from everyday laboratory equipment and could, we believe, be installed with advantage wherever this subject is taught.

C. D. Darlington.

H. C. Osterstock.

John Innes Horticultural Institution, London, S.W.19. June 30 .

\section{An Early Magdalenian 'Raclette' Industry in the Lower Thames Valley}

Is 1930, Dr. A. Cheynier described a nowlydiscovered industry of Early Magdalenian age, located at Badegoule in the valley of the Vézère, characterised by a large number of end-and sidescrapers made on flakes and showing vertical edgetrimming. He termed these specimens "raclettes"1. Mr. A. S. Barnes, who has made a special study of the Upper Palæolithic phases of the Dordogne, refers to this culture in a paper on the Magdalenian period 